\title{
The Evolution of the Buddhist Otherworld Empire in Early Medieval China
}

The perception of the afterlife as a mirror image of the living world is a widespread religious phenomenon among civilisations. As this mirror-image relation is conditioned by the natural and social surroundings of each cultural milieu, particular questions arise when a religion is translated from one cultural domain to another, as Buddhism was into China. One of the most striking aspects of popular Chinese Buddhism is the ubiquity of purgatorial and penitential liturgies that are performed as part of funerals, ancestral worship and religious festivals and involve communication with a bureaucratic pantheon for the sake of the well-being of the deceased and the living. This otherworld authority takes the form of a pre-modern Chinese bureaucratic empire ruled by the Indian Buddhist and local Chinese deities. This article attempts to unravel the evolution of the Buddhist use of this Chinese imperial metaphor in the period before the emergence of the more fully fledged imperial image presented in the Scripture of the Ten Kings during the medieval period. By examining early archaeological and mortuary texts, I will first show how the development of the "imperial metaphor" of otherworld authority began once Chinese feudal states were first unified as an empire during the Qin-Han period. The second section illustrates how the bureaucratic otherworlds that existed parallel in Indian and Chinese contexts were linked and amalgamated within Chinese Buddhism through the accommodation of certain religious concepts, such as abstinence days, transmigration and the afterlife fate of deceased kings and officials, which were formulated in Chinese Buddhist apocryphal scriptures and popular religious texts. Through this process of evolution, the profile of the Chinese Buddhist otherworld empire we are familiar with today was formed.

Seeking the essence of Christianity, Ludwig Feuerbach (1804-1872 CE) argued that "Religion is that conception of the nature of the world and of man which is essential to, i.e., identical with, a man's nature." Hence the image of God is identical to the image of man. Taking the ancient Greek gods as his example, Feuerbach made the point that this mirror-image relation means that the quality and nature of god are determined by social conditions in each cultural milieu. ${ }^{1}$ If god's image is a reflec-

1 Feuerbach, The Essence of Christianity, 19-20.

Note: The article is based on part of my research project on "The Early Formation of the Buddhist Otherworld Bureaucratic Empire in Early Medieval China”, which was generously sponsored by research fellowships of the Sheng Yen Education Foundation, the International Consortium for Research in the Humanities (IKGF) at the University of Erlangen-Nuremberg, and the Chiang Chingkuo Foundation (European region). I am very grateful for their munificent support.

๑ Open Access. (C) 2020 Frederick Shih-Chung Chen, published by De Gruyter. $($ BY-NC-ND This work is licensed under the Creative Commons Attribution-NonCommercial-NoDerivatives 4.0 License.

https://doi.org/10.1515/9783110597745-024 
tion of man's, and man's image varies in accordance with social conditions, can we apply this mirror-image relation to the cadre of the pantheon and social structure in general?

Writing of the journey to the afterlife narrated in the Book of the Dead, John $\mathrm{H}$. Taylor remarked that "the ancient Egyptians' interpretation of their universe was conditioned strongly by the environment and their experience of life."2 From early imperial China (from the second century BCE), too, there is unequivocal mortuary evidence of a common belief in an afterlife journey to a mirror-image counterpart of the living-world bureaucracy in the otherworld. Indeed, the prevalence of the "imperial metaphor" in perceptions of the otherworld has long been considered by Sinologists to be a distinctive feature of Chinese religions. ${ }^{3}$ With reference to early Indian Buddhism, scholars such as Bimala C. Law and Miyasaka Yūshō 宮坂有勝 have noted how the assemblies of gods and of monastic communities described in the Pāli canonical scriptures (Nikāyas) seem to parallel the public assemblies of the Kșatriya tribes at the time of the Buddha. ${ }^{4}$ In her work, Jane Baun has demonstrated the applicability of the mirror-image relation to perceptions of the otherworld conveyed by imperial and bureaucratic metaphors in the medieval Byzantine Apocrypha. ${ }^{5}$

If images of god and of the otherworld are conditioned by specific social milieus, particular questions arise in cases of a religion that has been translated from one cultural domain into another, as Buddhism was into China from around the beginning of the Common Era. How did Buddhism put down roots in foreign soil so successfully that its otherworld metaphors gained general acceptance, supplanting even those of local religions to assume the chief role in determining the fate of the deceased in the afterlife? By examining key archaeological and textual sources from early medieval China (from the second century CE to the seventh century CE) concerning the afterlife journey and transmigration, this paper seeks to show how Buddhism was able to transform the Chinese otherworld empire.

One of the most compelling popular aspects of East Asian Buddhism is the ubiquity of purgatory and repentance liturgies, which are performed as part of funerals, ancestral worship, and religious festivals. Their apparent dominance caused modern scholars until the 1990s to label this aspect of East Asian Buddhism derogatorily as “Funeral Buddhism”. Tamamuro Taijo 圭室諦成 first proposed this term in the 1960s, ${ }^{6}$ because the intensive performance of funeral rites by priests for financial gain had led to the corruption of monastic communities and the neglect of spiritual teaching. From another perspective, however, the very prevalence of funeral litur-

2 Taylor, Journey through the Afterlife, 16.

3 Feuchtwang, The Imperial Metaphor.

4 Law, Heaven and Hell in Buddhist Perspective, 14-15; Law, Some Kșatriya Tribes of Ancient India, 87-88. Miyasaka Yūshō, Bukkyō no kigen, 341-345.

5 Baun, Tales from Another Byzantium.

6 Tamamuro Taijo, Sōshiki Bukkyō. 
gies demonstrates how successfully Buddhism provided its East Asian adherents with convincing answers to questions regarding their ultimate fate and their wellbeing in the afterlife.

The Chinese Buddhist funeral liturgy rests on the soteriological belief that the chanting of repentance scriptures and the performance of purgatorial rites by Buddhist clergy are effective means of nullifying the past sins and bad karma of the deceased, ensuring salvation in the otherworld. There the dead will be judged by judicial deities, who decide whether to condemn them to tormenting Hells, dispatch them to a better rebirth, or admit them to the Western paradise (Sukhāvatī). The funerary liturgy usually starts with a priest chanting a type of mortuary petition on behalf of the deceased, which is addressed to the bureau of the otherworld authority for protection and salvation. The petition, an actual document, is then burned. An example of the sample texts of such Buddhist funeral petitions is the Official Document of the Bureau of Three Treasures (Sanbaosi dieben 三寶司牒本) to the Otherworld Bureau, authorised by Amitābha Buddha, "Lord of the Western Paradise" and endorsed with the red print of the seal of the four Chinese characters of the Seal (yin 印) of the Three Treasures: fo 佛 (the Buddha), fa 法 (the Dharma), and seng 僧 (the sangha, the Buddhist monastic community), a text commonly used at Buddhist funerals nowadays. ${ }^{7}$ Another earlier example is the seventeenth-century woodblock of model texts for funeral passports to the Pure Land, endorsed by the monogram of Tathāgata Sākyamuni, which was found in the Bút Tháp Temple 寧福寺, Vietnam. ${ }^{8}$ These Buddhist funeral petitions were similar in form to a pre-modern Chinese official passport, but they were supposed to have been issued by an otherworld empire ruled by Amitābha Buddha or Śākyamuni Buddha, respectively, and the Bureau of Three Treasures. The use of this type of funeral document illustrates Buddhist appropriation of the idiosyncratic concept of bureaucratisation, a characteristic of indigenous Chinese religion. The first part of this paper examines the origins of this concept in the early Chinese context.

\section{The Beginning of the Early Chinese Otherworld Bu- reaucracy}

The bureaucratic concept has long been considered a pillar of Chinese civilisation, and the mirroring of the this-worldly bureaucracy in the imagery of deities and the structure of the pantheon strikes many modern sinologists as an idiosyncratic characteristic of Chinese popular religions. The earliest extant unequivocal texts proving

7 Chen, "The Transformation of Concepts of Bureaucratization of the Other World," 369, fig.1.

8 I would like to thank Professor Jim Kemp for showing me the pictures of the carvings that he surveyed. 
the use of funerary petitions that resemble Chinese imperial documents date as far back as the Han dynasty (202 BCE-220 CE). The earliest substantial account of communication with an otherworld bureaucrat found so far is actually a story written on a bamboo-slip that has been excavated from Tomb 1 at Fangmatan 放馬灘, Gansu province, dated to the late Warring States period (approximately 230 to 220 BCE). Mentioned in the Administrator of Di’s 邸 report to the Qin 秦 Royal Scribe, it tells of the resurrection of a person called Dan 丹, who had committed suicide after stabbing someone. His patron, $\mathrm{Xi} \mathrm{Wu}$ 犀武 (presumed to be the famous general of the Wei 魏 state ${ }^{9}$ ), considered that Dan was not yet fated to die, so he made a declaration to this effect to the Scribe of the Director of the Life-Mandate in the underworld, an official called Gongsun Qiang 公孫強 (彊) (probably another historical figure, who had been an officer of the Cao 曹 state in the Spring and Autumn period) ${ }^{10}$. Eventually, after three years, Dan was resurrected from the tomb, and at the end of the story he explains how to conduct proper funeral rituals. ${ }^{11}$ In the view of Donald Harper, this narrative suggests that the conception of a dialectical relationship between the this- and the otherworldly bureaucracies was already part of the popular religions of the Warring States period. ${ }^{12}$ Lothar von Falkenhausen similarly argued that it implies the early formation of a belief that "the afterworld of the dead, though hermetically separate from ours, was nevertheless a mirror-image of the world of the living, with a hierarchy of ghosts corresponding to the administration system of the secular state". ${ }^{13}$ The story of Dan shows the registration of human lifespans to be the responsibility of an otherworld bureaucrat, and the identification of the Scribe of the Director of the Life-Mandate with the historical figure of Gongsun Qiang is a very early example of the Chinese popular belief that an official could after death assume a similar role in the otherworld bureaucracy. As this belief seems compatible with the Buddhist theory of transmigration, it was later frequently applied by Chinese Buddhists to the bureaucratisation of the Buddhist otherworld.

\section{Early Funerary Documents}

Although belief in an otherworld bureaucracy is already implied in sources predating the first emperor, the earliest unequivocal and concrete evidence of the use of funeral texts in the form of official documents comes from the Former Han dynasty (206 BCE-9 CE). A limited number of texts involving communication with the otherworld bureaucracy are known from this period, most of which have been excavated

\footnotetext{
9 Simaqian, Shiji, 4:164.

10 Simaqian, Shiji, 35:1573.

11 Li Xueqin, "Fangmatan jianzhong de zhiguai gushi."

12 Harper, "Resurrection in Warring States Popular Religion," 16.

13 Falkenhausen, "Sources of Taoism," 8.
} 
in the Hubei and Hunan provinces. ${ }^{14}$ Here is one of the earliest documents intended to inform the otherworld bureaucracy of the coming of the deceased, gaodi ce 告地 策. It is written on a wooden tablet discovered in tomb No. 18 of Gaotai at Jingzhou in Hubei:

On the day of gengzi of the tenth month whose first day is bingzi of the tenth year of Emperor Wen [173 BCE], Qi from Zhongxiang dares to declare as follows: the adult woman Yan from Xin'an is willing to move to Andu with the adult male servants, Mr. So-and-Sos, and the female servant Fang. I notify Andu to receive the household registration and report when the document arrives. I dare to declare. On the day of gengzi of the tenth month, the aide of Jiangling, Mr. Long, sincerely transmits the document to the aide of Andu.

Ting signed it

[On the other side]

Chan signed it ${ }^{15}$

The text takes the form of an official document transferring the registration of a deceased lady from Jiangling 江陵 to Andu 安都, her destination in the otherworld. (The aide of Andu is one of the otherworld bureaucrats also mentioned in land contracts of the Northern-Southern dynasties. $)^{16}$ It even seems to have been written and signed by local secular officers (or at least was written as if it had been). ${ }^{17}$ On another tablet, the name of the destination "Andu" is inscribed at the top, while "the seal of the aide of Jiangling 江陵丞印” appears in smaller characters at the bottom. ${ }^{18}$ This suggests that it was considered a genuine official document, and contact between the bureaucrats of the living world and the bureaucrats of the otherworld was being straightforwardly equated with contact between different living-world bureaux.

14 Hubeisheng jingzhou bowuguan 湖北省荆州博物館, Excavation, 222-223; The Hunan Provincial Museum and IAAS, "Changsha mawangdui er san hao hanmu fajue jianbao;" Archaeological Team of Han Tomb, 168, "Hubei jiangling fenghuangshan yiliuba hao hanmu fajue jianbao;" Qiu Xigui [Chiu Hsi-kuei], "Hubei jiangling fenghuangshan shihao hanmu chutu jiandu kaoshi;” Hubeisheng wenwu kaogu yanjiusuo 湖北省文物考古硎究所 ed., Suizhou kongjiapo hanmujiandu, 197.

15 Hubeisheng jingzhou bowuguan, Excavation, 222-223: 七年十月丙子朔[庚子], 中鄉起, 敢言之: 新安大 女燕自言與大奴甲, 乙, [大]婢妨徙安都, 謁告安都. 受[ 數書到爲報, 敢言之十月庚子江陵龍 氏丞敬移安都丞. 亭手(背)產手.

16 Liu Zhaorui, “Anducheng yu Wuyijun.”

17 There are different interpretations as to why the two sides of the tablet were inscribed by different people. See Xing Yitian, "Hunan longshanliye J1(8)157 he J1(9)1-12hao qindu de wenshu gocheng, biji he yuandang cunfang xingshi (lienzai er)."

18 Hubeisheng jingzhou bowuguan, Excavation, 222-223. 


\section{The Development of the Chinese Otherworld Empire}

From the end of the first century CE, a different type of funeral document, called a “tomb-quelling text” (zhenmu wen 鎭墓文), gradually became popular in mortuary practice. Tomb-quelling texts for the dead were written on pottery jars in order to deflect evil from the tomb and its occupant. Anna Seidel describes them as passports endorsed by the Supreme Celestial Emperor (or the Yellow God) and his envoy that were intended to introduce the dead to the subterranean administration. The quantity of tomb-quelling texts increased dramatically after the mid-second century. ${ }^{19}$ Here is one from $174 \mathrm{CE}$ :

On the sixteenth day, gengshen, of the twelfth month, whose first day is yisi of the second year of Xiping (5 February, $174 \mathrm{CE}$ ), the Celestial Emperor's Envoy informs the three mounds and five tombs of the Zhang family to the Left and Right officers of the tomb, the grave-owner in the centre, the Aide and Director of the Sepulchre, the Chief Director of the Sepulchre, the Chief of the Commune of the Gate of Souls, the Brigade Commander of the Sepulchre, etc., and dares to announce and transmit (this document) to the Aide of the Mound and the Earl of the Tomb, the Sub-terrestrial Two Thousand Bushel Officials, the Marquis of the Eastern Sepulchre, the Earl of the Western Sepulchre, the Official of Underneath, the Squad Leader of Haoli, etc. Today is an auspicious day. It is for no other reason that the deceased man, Zhang Shujing, who was ill-fated and died young, came down to rest in this mound. The Yellow God governs the five sacred peaks. He takes charge of the welfare of the living. He summons the spirit souls and vital souls, and controls the archives of the dead. The living built the high terrace. The dead come to be buried deeply alone. Eyebrows and beard would fall and become dust and ash. Today I therefore offer the medicine of recovery, which is intended to ensure no death for later generations. There are nine stems of Shangdang ginseng, intended to substitute for the living. The lead figures substitute for the dead. The yellow beans and seeds of melons are held by the dead to pay the otherworld tax. The system is set up to avoid affliction and ward off punishment incurred by offences towards the land so that disasters and misfortunes will not happen. This message should be conveyed in order to prevent the local bureaucrats of the netherworld troubling the Zhang family. Promptly, promptly, in accordance with the statutes and ordinances. ${ }^{20}$

Tomb-quelling texts not only inherited the basic structure and format of official documents, but also comprised explicit religious ideas, which led to some adjustments

\footnotetext{
19 Seidel, "Traces of Han Religion in Funeral Texts Found in Tombs;" Wu Rongzeng, "Zhenmuwen zhong suo jiandao de donghan daowu guanxi," 56. Liu Yi, Jingtian yu chongdao, 17-33.

20 Ikeda On 池田溫, “Chugoku rekidai boken ryakko,” 273, no. 6: 喜平二年十二月乙巳朔十六日庚 申, 天帝使者告張氏之家, 三丘五墓, 墓左墓右, 中央墓主, 塚丞塚令, 主塚司令, 魂門亭長, 塚中游擊

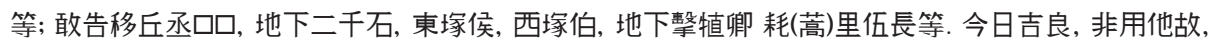
但以死人張叔敬, 薄命蚤死, 當來下歸丘墓. 黃神生五获, 主生人祿; 召魂召隗, 主死人籍. 生人筑高臺, 死人歸深自貍. 眉須以落下爲土灰. 今故上復除之藥, 欲令後世無有死者.上黨人參九枚, 欲持代生人, 鉛人持代死人, 黃豆瓜子死人持給地下賦. 立制牡庽, 辟除土然, 欲令禍殊不行. 傳到約勒地吏, 勿復煩 擾張氏之家. 急急如律令.
} 
to the texts. First, petition to the otherworld on behalf of the dead person and his relatives is no longer filed by a local bureaucrat, but by the Celestial Emperor's Envoy. Secondly, there is a difference of tone. In the earlier Former Han funeral texts, the attitude of the local bureaucrat towards his otherworld counterpart was generally neutral. As the Chinese scholar Chen Zhi 陳直 comments, the whole bureaucratic process was based on the living-world principle of doing "official business according to official principle". ${ }^{21}$ By contrast, the main concerns of tomb-quelling texts were not only to exorcise evil influences and absolve the dead from punishment, but also, in many cases, to demand special blessings and protection from otherworld bureaucrats. The grave goods mentioned in this text, for example, were payment of otherworld tax and substitution for the dead to fulfill their underworld corvée service in exchange for the protection from the otherworld administration. ${ }^{22}$ In addition, almost every tomb-quelling text highlights the need to clarify the registration of the dead and the living in their respective realms, as any muddling of this registration would cause misfortune toward the living family.

In tomb-quelling texts, the Celestial Emperor's Envoy issues orders to a wide range of otherworld officials of provincial commandery-kingdom level. The Two Thousand Bushel Officials of the Otherworld (routinely mentioned in texts) correspond to leading officials at the commandery-kingdom level of provincial government during the Han dynasty. In fact, the contact between the Celestial Emperor's Envoy and the otherworld provincial-level bureaucrats here runs exactly parallel to the role within Han administration of the Special Imperial Envoy. The latter was dispatched by the emperor to supervise local government and tackle problems caused by maladministration and incompetent bureaucrats, particularly the Two Thousand Bushel Officials. There are many historical accounts of how the Imperial Special Envoy acted as a Messenger of Justice from the imperial court, impeaching incapable officials and thus winning the gratitude of the populace. ${ }^{23}$ For instance, in the official history of the Later Han dynasty, Hou Han shu 後漢書, it is recorded:

[In the first year of Han'an of Emperor Shun's reign (142 CE)], the emperor issued an edict to dispatch eight envoys to make a tour of inspection of people's conduct. Those chosen all possessed great fame and they were promoted and given the title of Palace Attendant. Palace Attendant Du Qiao, Probationary Grand Master of the Imperial Household Zhou Xu, Former Inspector of Qing State Feng Xian, Chief Steward for Writing Luan Ba, Attendant Censor Zhang Gang, Inspector of Yan State Guo Zun, and Aide to the Defender-in-Chief Liu Ban were all promoted to the rank of Probationary Grand Master of the Imperial Household and dispatched to their respective states and commanderies. If Inspectors or the Two Thousand Bushel Officials were found to have committed evident bribery or crimes, [the Special Envoys] were to report them to the central government by the Fast Post Horse. If the criminal official was not above black-ribbon rank, he was to be arrested immediately. Loyal officials with integrity, who

21 Chen Zhi, "Guanyu 'Jiangling cheng' gao 'dixia cheng'," 76.

22 Chen, "The Transformation of Concepts of Bureaucratization of the Other World," 77-81.

23 Huang, Lianghan xingzhengshi shouce, 50-55. 
worked for the benefit of the public and were trusted by the common people, were also to be reported to the imperial court. Accordingly, the eight envoys all received this mission at the same time. The world called them 'the Eight of outstanding character'. ${ }^{24}$

The Eight Trigram Deities, the eight messengers of the supreme deity, the Grand One, are frequently mentioned in Daoist scriptures such as in the Laozi zhong jing 老子中經 (“Central Scripture of Laozi”) as embarking on tours to inspect the behaviour of human beings on eight seasonal days. In his research on one of these eight Imperial Envoys, Luan Ba 欒巴, Professor Liu Cunren (Liu Ts'un-yan, 柳存仁) pointed out that the Eight Trigram Deities were probably modelled on these eight Imperial Envoys in this historical event described in the Hou Han shu. ${ }^{25}$ Priests seem to have used the title of Celestial Emperor's Envoy in tomb-quelling texts in order to mirror the role of the Special Imperial Envoys of the Han dynasty. In taking on the new religious concerns expressed in the tomb-quelling texts, the passport to the otherworld bureau ceased to be part of the living-world bureaucratic process and became a passport administered by religious cults for religious ends.

The advent and growing popularity of tomb-quelling texts coincided with the earliest accounts of organised religious cults in Chinese history. They are therefore thought to have been used by proto-Daoist cults. Angelika Cedzich, in her study of the stele of the Later Han Celestial Master community in Sichuan, suggests that there was a symmetrical relationship between the community and the invisible regime in which they believed. The Celestial Master priests were thought capable of managing both these worlds. She comments:

The otherworldly bureaucracy was closely linked to a symmetrical organization on earth, whose representatives, the jijiu priests of the Celestial Master tradition, had the power to directly influence the proceedings on the other side. The spirit-administration became an inseparable part of a greater whole managed by a this-worldly clergy. ${ }^{26}$

As she also notes, the duties of the jijiu, the delegate priests of the Celestial Master, included collecting taxes and keeping records, tasks normally performed by local administrators. ${ }^{27}$ This implies that they might have taken over this role. Although we do not know from the Later Han tomb-quelling texts who exactly the Celestial Emperor's Envoy was, the structure of his communication with the invisible realm suggests that his functions paralleled those of a Celestial Master priest.

24 Fan Ye, Hou Han shu, 61:2029: 時詔遣八使巡行風俗, 皆選素有威名者, 乃拜舉爲侍中. 舉侍中杜 喬, 守光祿大夫周朷, 前青州刺史馮羡, 尚書欒巴, 侍御史張綱, 亮州刺史郭遵, 太尉長史劉班並守光 祿大夫, 分行天下. 其刺史, 二千石有藏罪顯明者, 驛馬上之; 墨綬以下, 便輙收舉. 其有清忠惠利, 爲 百姓所安, 宜表異者, 皆以狀上. 於是八使同時俱拜, 天下號曰八俊.

25 Liu Cunren [Liu Ts'un-yan], "Was Celestial Master Zhang a Historical Figure?”

26 Cedzich, "Ghosts and Demons, Law and Order," 32-33.

27 Cedzich, "Ghosts and Demons, Law and Order," 30. 
The transition from Former Han funeral texts to Later Han tomb-quelling texts exemplifies the transformation of religious perceptions of the otherworld through the adoption of bureaucratisation. This pattern was commonly replicated by later Daoism and imported Buddhism in order to facilitate their propagation - as can still be seen in modern-day funeral texts.

\section{Early Buddhist Appropriation}

During this period of transition in the Han dynasty, the introduction of Buddhism was first recorded in official Chinese imperial history. Indigenous religions included belief in an afterlife journey in a bureaucratised otherworld. The basic doctrine of Buddhism, by contrast, taught a model of transmigration (the cycle of rebirth), nirvāna (liberation), and karmic retribution. This was novel to the Chinese in key respects: the destination of the afterlife, its ultimate soteriological goal, and the mechanism of the transmigration cycle. Nevertheless, these Buddhist doctrines came to permeate Chinese religious beliefs in the ensuing early medieval period and became an integral part of Chinese popular religion that survives until today. On the basis of his research on early Buddhism in India, Gregory Schopen points out that as it spread from Northern India, Buddhism always encountered different cultures and developed ways of surviving in foreign milieus by finding a place in the local landscape. ${ }^{28}$ The fundamental doctrines of Buddhism won acceptance among the Chinese in the early medieval period through a smooth process of development that connected the early Chinese religion's concepts of otherwordly bureaucracy with similar ideas existing in Indian Buddhism. This process may be seen in early medieval popular Buddhist scriptures, accounts, and ritual texts, particularly the scriptures on the rentian jiao 人天教 (“Teaching of Men and Gods”).

The Teaching of Men and Gods belongs to the most basic category of Chinese Buddhist taxonomy of the Buddhist doctrine, conveying the core idea of karmic retribution and instructing lay people about the Five Precepts and the Ten Merits whereby they might gain a better rebirth. ${ }^{29}$ Despite their popularity, many such

28 Schopen, Buddhist Monks and Business Matters, 360.

29 Although the teaching has an Indian origin, the term rentian jiao was probably first proposed by a lay Chinese Buddhist, Liu Qiu 劉虬 (438-495 CE), during the second half of the fifth century. The Teaching of Men and Gods was very popular during the Northern and Southern dynasties. Its social organization is known as yiyi 邑義, which is an association of lay believers directed by a monastery. Their activities have been further revealed by the inscriptions on the Northern Wei caves. The rentian jiao was the imperative dynamic for Buddhist revival after the persecution of Buddhism by the Emperor Taiwu 太武 of the Northern Wei (446-452 CE) and the leading figures in this revival were a group of monks from Liangzhou 涼州, particularly Tanyao 是曜. The rentian jiao is similar to the "affective religion", defined by Richard Gombrich in his observation of Theravāda Buddhism in Ceylon; it is contrasted with the "cognitive religion" pursued only by the religious elites who sought 
scriptures are considered apocryphal due to the hybrid quality of their content. In early medieval Chinese Buddhist scriptures of the Teaching of Men and Gods, the celestial process of inspecting and recording people's deeds and deciding those deeds' karmic consequences in terms of lifespan and future rebirth is administered by a hybrid otherworld empire including both Indian Buddhist and Chinese bureaucratic deities. This hybrid imperial metaphor was in fact created by Chinese Buddhists by forging a link between parallel religious concepts of the celestial inspection and recording of human behavior on religious days of abstinence described in respective Indian Buddhist and in Chinese Daoist scriptures. This integration of the other religion's elements is also evident in contemporary Buddhist funeral documents. According to the Buddhist doctrine of transmigration, a person with substantial merit can be reborn as a celestial being or even a deity. This concept is fully compatible with the Chinese belief that kings or officials could after death assume similar positions in the otherworld, so a dead Chinese king or official might turn into a Buddhist god. In this way, Buddhism was able to assimilate Chinese popular cults of sacrifice to dead kings and officials. In the following sections, I show how a Buddhist otherworld bureaucratic empire was gradually formed during the early medieval period through engagement and interplay in respect of abstinence days and the transmigration of otherworld official deities.

\section{The Amalgamation of Parallel Bureaucratic Other- worlds via similar Concepts of Abstinence Days}

The Jingdu sanmei jing 淨度三昧經 ("Samādhi-Sūtra of Liberation through Purification”) and the Tiwei boli jing 提謂波利經 (“Sūtra of Trapuṣa and Ballika”), both composed in the fifth century CE, are usually viewed together as the most influential and popular apocryphal Buddhist sūtras of rentian jiao during the Northern and Southern dynasties. ${ }^{30}$ Both scriptures contain an account of the bawang ri 八王日 ("Days of the Eight Kings"), abstinence days commonly observed by Buddhists in the early medieval period. This account provides a good example of how a hybrid Chinese Buddhist otherworld bureaucratic empire was intentionally formulated by

\footnotetext{
ultimate liberation through meditation, whereas "most people, monks included, devoted themselves exclusively to acts of merit (pinkam), the aim of which is a good rebirth in heaven or on earth". Gombrich, Traditional Buddhism in the Rural Highlands of Ceylon, 377; Gregory, "The Teaching of Men and Gods;" Gregory, Inquiry into the Origin of Humanity, 110-127; Tsukamoto Zenryū, Shina Bukkyō shi kenkyū: Hokugi-ben, 341-346.

30 Lai, "The Earliest Buddhist Religion in China," 12-14; Gregory, "The Teaching of Men and Gods," 254-258; Abe, Ordinary Images, 208-257; Tokuno, "Byways in Chinese Buddhism;" Ziegler, "The Sinification of Buddhism as Found in an Early Chinese Indigenous Sūtra;" Chen, "Who Are the Eight Kings in the Samādhi-Sūtra of Liberation through Purification?”
} 
linking parallel religious ideas of periodic abstinence days and associated metaphors of inspection and recording of human deeds by otherworld bureaucratic deities in Indian Buddhist and Chinese Daoist texts. ${ }^{31}$ It emphasises the importance of abstinence on the Days of the Eight Kings, which are identical with the Daoist eight seasonal days stipulated by the fourteenth section of the Laozi zhong jing. On these days, the otherworld bureaucratic deities (especially the Eight Trigram Deities) ${ }^{32}$, each associated with a particular part of the human body, assembled at the imperial court of the Celestial Emperor, the Lord of the Grand One, to report the deeds of human beings and decide whether to prolong or to curtail their lives. People imagined the assorted bureaucratic deities on these occasions removing their names from the register of the dead and thereby lengthening their lives..$^{33}$ According to the Jingdu sanmei jing, all sentient beings in the three realms of samsāra (transmigration) are governed by King Yama, who is the Son of Heaven (one of the titles of the Chinese emperor) of the otherworld bureaucratic empire and also a subject of the Buddha. ${ }^{34}$ On the Days of the Eight Kings, the celestial bureaucratic gods, along with other otherworld bureaucrats (both Indian Buddhist and indigenous Chinese deities), receive reports submitted by the Four Celestial Kings on the fifteenth and thirtieth days of the lunar month, inspect the deeds of individuals, and update their records. Only by observing the Buddhist Five Precepts and Ten Issues on these days could one have previous sins nullified and additional merit added to one's record in the hope of living longer and avoiding rebirth as an inferior being or falling in the hells in a future life. ${ }^{35}$

The key to unravelling how a text integrating Buddhist and Chinese beliefs, like the Jingdu sanmei jing, was composed hinges on the reason why major Indian Buddhist deities - such as Indra, the thirty-two devas or guardian ministers, and the Four Great Kings - are accompanied by Chinese deities - such as the Director of the Life-Mandate, the Director of Records, the Five Emperor Messengers, and the mystical Eight King Messengers - in the account of how otherworld bureaucrats investigate human deeds on the Days of the Eight Kings. My analysis reveals that they are associated with otherworld bureaucratic inspection of sentient beings on the six Buddhist abstinence days, as depicted in the early Buddhist text of the Four Great Kings, and the eight Daoist seasonal days in the Laozi zhong jing. Also, the merits

31 Chen, "Who Are the Eight Kings in the Samādhi-Sūtra of Liberation through Purification?," 5869.

32 The association between the eight seasonal days and the Eight Trigrams was probably first mentioned by Zheng Xuan 鄭玄 (127-200 CE) in one of the commentaries on the Book of Changes allegedly written by him, the Yiwei tonggua yan 易緯通卦驗. Yoshijirō, Kan'eki kenkyū, 199; Ziegler, "The Sinification of Buddhism as Found in an Early Chinese Indigenous Sūtra," 168.

33 Chen, "Who Are the Eight Kings in the Samādhi-Sūtra of Liberation through Purification?," 6568.

34 Jingdu sanmei jing, Zangwai fojiao wenxian, 248.

35 Jingdu sanmei jing, Zangwai fojiao wenxian, 262, 265-266. Chen, "Who Are the Eight Kings in the Samādhi-Sūtra of Liberation through Purification?," 61-62, 75-78. 
obtainable by observing the six Buddhist abstinence days correspond to those obtainable on the eight Daoist seasonal days; and an increase in lifespan is promised in the Account of the Days of the Eight Kings. ${ }^{36}$ The discovery of these parallels enables us to see that the mystical Eight King Messengers in the Account of the Days of the Eight Kings are probably a Buddhist appropriation of the key inspector deities on the eight seasonal days, the Eight Trigram Deities mentioned in the Laozi zhong jing. Furthermore, this helps us identify the enigmatic eight deities with the eight trigram symbols inscribed above them on the bottom layer of many Northern Liang 北涼 (Liangzhou) votive stūpas from Turfan and Dunhuang (dated to around the first half of the fifth century CE); they are probably the Eight King Messengers in the accounts of the Account of the Days of the Eight Kings found in both the Jingdu sanmei jing and the Tiwei boli jing. ${ }^{37}$

Scholars such as Bimala Law, Miyasaka Yūshō and T. W. Rhys Davids have pointed out that the narration of the assembly of deities in the hall of Indra's court and his role in Buddhist scriptures (such as the text of the Four Great Kings) actually mimic the public assembly of the Kșatriya tribes and the role of a tribal leader. ${ }^{38}$ According to a commentary by the fifth-century Buddhaghosa on the text of the Four Great Kings, the bureaucratic process of karmic recording on the six abstinence days involves first writing on palm leaves and then engraving on golden plates, procedures that reflected bureaucratic practices in pre-modern India. ${ }^{39}$ By contrast, in the Laozi zhong jing and the Account of the Days of the Eight Kings, the process is based on the administrative paperwork of the Chinese imperial bureaucracy. Thus the Indian imperial metaphor of inspections and the assemblies in the courts of the Four Celestial Kings and of Indra, as depicted in the text of the Four Great Kings, is incorporated into the local Chinese model in the Account of the Days of the Eight Kings.

Furthermore, this hybrid bureaucracy of the otherworld appears not only in scriptural texts; it also manifests in subsequent Buddhist funeral passports of the sixth century. One such text was inscribed on a wooden tablet and dedicated to Lady Wang Jiangfei: ${ }^{40}$

36 Chen, "Who Are the Eight Kings in the Samādhi-Sūtra of Liberation through Purification?,"

37 Chen, "Who Are the Eight Kings in the Samādhi-Sūtra of Liberation through Purification?," 6973.

38 See n. 4 and Dialogues of the Buddha, ed. Davids and Davids, 296.

39 Manorathapūrañ. Buddhaghosa's Commentary, ed. Walleser and Kopp, 2: 233-234. Salomon, Indian Epigraphy. A Guide to the Study of Inscriptions, 113-115; Chen, "Who Are the Eight Kings in the Samādhi-Sūtra of Liberation through Purification?," 63-65.

40 Aside from the funeral passport of Lady Wang Jiangfei in Shandong, we have a group of relatively simplified Buddhist funeral documents addressed to the God of the Five Paths (dating from the mid-sixth to the mid-seventh century), which were excavated in tombs in Turfan. See Hansen, "Path of Buddhism into China;" Chen, "Buddhist Passports to the Other World." 
On the sixth day of the seventh month, whose first day is yichou of the fourth year, Guisi of Wuping [573 CE] of Northern Qi. The disciple of Śākyamuni Buddha Gao Qiao dares to declare to the Earth of Shengwan li of Zhentan kingdom [China]. Although Gao Qiao was initially from the Bohai commandery of Ji zhou, he has continuously lived in Shengwan li of Yidu county of the Qi commandery of Qing zhou because of his official position. His wife, Wang Jiangfei, who is seventy-seven years of age, had been ill for many years and medical treatment did not help. Her life came to an end suddenly on the sixth day of this month. She left the three lights above, the sun, moon and stars, and ended up down in Haoli. ${ }^{41}$ During her lifetime, Jiangfei dedicated herself to the Ten Virtues, adhered to the Five Precepts, and performed the entire fasts, including the three month-long fasts each year and six-day fasts each month, without missing any of them. Now she is dispatched by the preceptor, the Lord of the Grave and the Lord of the Mountain, and she will be picking flowers for the Buddha and will not return. When Jiangfei's life came to an end, the Celestial Emperor [Indra in this context] held flowers to welcome her spirit, and the Great Potentiality ${ }^{42}$ came to receive her soul. I order you, the underground Nüqing 女 青, ${ }^{43}$ to issue an edict to the Great God of the Five Paths and the officers in Charge of the Soil as follows: Wherever Jiangfei's clothes, property, sundry goods and personal luggage pass by, you must not detain them. If they are questioned and detained, in this world Rudra will crush

41 The southern side of Mount Tai was believed to be the final destination of the dead in the otherworld no later than the Han dynasty.

42 The Great Potentiality; or the great powers of buddhas and bodhisattvas which transform themselves into others.

43 Scholars have been baffled by the meaning of the term Nüqing 女青 in Chinese religious writing, though Nüqing 女青 is the name of a herb that appears in several Chinese medical scriptures. Bencao jing, ed. Cao Yuanyu, 209; Mingyi bielu, ed. Shang Zhijun, 232. According to the thesaurus Kuangya 廣雅, by the third-century Zhang Yi 張揖 (juan 10, page 2), Nüqing 女青 is a kind of herb also called wuge 烏葛 (“Dark Vine”). The Shennong bencaojing 神農本草經 says that Nüqing 女青 is a kind of vine, used mainly for the diseases caused by noxious agents produced by various parasites. It can expel venomous $q i$, kill ghosts, or cure diseases caused by heat or fever. It can also dispel misfortune (治畫毒. 逐邪惡氣. 殺鬼. 溫瘧. 辟不祥). The early medieval Daoist scripture Nüqing guilü 女青鬼律 (“Code of Nüqing for [Controlling] Demons”) is a text about exorcism. From the fourth century onwards, the ordinance of Nüqing became a kind of standard ending phrase that frequently appears in Chinese mortuary texts. There is a dispute among scholars about whether the Code of Nüqing for (Controlling) Demons is equivalent to the ordinance of Nüqing in the mortuary texts. In the mortuary petition of Wang Jiangfei, the herb Nüqing is treated as an otherworld deity and made responsible for issuing edicts to other otherworld bureaucratic deities to protect the property and safety of the deceased. It seems that Nüqing represents an authority in the otherworld. In this context, the ordinance of Nüqing means the decree issued by Nüqing. The argument among scholars centers on whether the ordinance of Nüqing stems from a specific statute on mortuary issues in the Code of Nüqing for (Controlling) Demons that cannot be found in the extant version. However, if we interpret the ordinance of Nüqing as an ordinance issued by the authority Nüqing, as in the regular ending phrase of the mortuary document "in accordance with the statutes and ordinance", in my opinion, it does not necessarily denote any specific statute, but is simply a claim that the matter should be dealt with under that authority. See Strickmann, Chinese Magical Medicine, 80-81; Bai Bin, "Wujin nanchao maidiquan mingci he yiwushu de daojiao kaogu yanjiu," 83; Bai Bin and Dai Lijuan, "Shicong kaohucailiao kan Nüqing guilü dechengshushidai yu liuxingdiyu;" Li Zhitian, "Nüqingguilü yu caoqi tianshidao dixiashijie de guanliaohua wenti;" Seidel, "Traces of Han Religion in Funeral Texts Found in Tombs," 41. Peterson, "Demon Statute of Feminine Verdure;” Dudink, “Nüqing guilü.” 
you into pieces like the branches of the arjakamañjari tree. In case you do not know who the scribe and the reader are, when the document comes, let it be said that Bodhisattva Avalokiteśvara is the scribe and Bodhisattva Vimalakirti is the witness reader. So I transmit this document. Promptly, promptly, in accordance with the statutes and ordinances. ${ }^{44}$

This funeral passport was directed by Buddhist disciple and government official Gao Qiao to the administration of the otherworld on behalf of his late wife. Its bureaucratic format and structure bear significant resemblance to those of Han funeral texts, apart from the fact that the content is dominated by Buddhist ideas and divinities. The syncretic otherworld administration it portrays includes both Buddhist and Chinese deities, though it is ruled by Buddhist divinities. That Lady Wang Jiangfei's observance of the Buddhist Five Precepts and Ten Merits when she was alive is the guarantee of a better afterlife for her in Indra's Heaven, and the document was issued and endorsed by Bodhisattva Avalokiteśvara and Bodhisattva Vimalakirti. The appearance of mortuary documents of this type during the sixth century demonstrates that basic Buddhist doctrines and the transformed metaphor of a hybrid Chinese Buddhist otherworld authority were not restricted to the popular scriptures of rentian jiao, but had entered religious practice.

\section{The Transmigration of Deceased Kings and Offi- cials into Otherworld Divinities}

As discussed above, in the story of Dan found in Tomb 1 in Fangmatan the dead mortal, Gongsun Qiang 公孫強, previously an officer, was reincarnated as a bureaucrat in the otherworld, namely as the Scribe of the Direction of the Life-Mandate 司 命史. According to K. R. Norman's research on the Buddha's view of deities in Indian Buddhism, otherworld deities were themselves seen as subject to the cycle of samsāra of death and rebirth, and thus to karmic retribution. Each deity should be regarded as the title of a divine position rather than a single divine individual. ${ }^{45}$ This concept is also mentioned in the Jingdu sanmei jing, which states that "the lifespan of devas is also finite” (諸天亦自有歲盡). ${ }^{46}$ Erik Zürcher has noticed an in-

44 Taozhai cangshi ji, ed. Duan fang, 13:6a-8a. Asami Naoichirō, "Chūgoku Nambokuchō jidai no sōsō buns hui:” 北齊武平四年歲次癸巳七月乙丑六日庚午, 釋迦文佛弟子高僑敢告: 口灣里地振坦國 土, 高僑元出冀州勃海郡, 因宦仍居青州齊郡盆都縣㵴口裏. 其妻王江妃, 年七十七, 遇患積稔, 醫療無 損, 忽以今月六日命過壽終. 上辭三光, 下歸蒿裏. 江妃生時十善持(持)心, 五戒堅志, 歲三月六, 齋戒 不閶. 今爲戒師藏公, 山公等所使, 與佛取花, 往知(之)不返. 江妃命終之時, 天帝抱花, 候迎精神, 大 權口往接侍靈魂. (勅)汝地下女青詔書五道大神, 司坺之官, 江妃所衣資雜物, 隨身之具, 所逕(經)之 處, 不得訶留. 若有留詰, 沙訶樓碎汝身首如阿梨樹枝. 來時, 不知書讀是誰. 書者觀世音, 讀者維摩 大士. 故移, 急急如律令.

45 Norman, Collected Papers, 1.

46 Jingdu sanmei jing, ed. Zangwai fojiao wenxian, 266. 
teresting resemblance between this Buddhist concept of rebirth in a divine position and the Daoist concept of deities as officials in the immortal bureaucracy. ${ }^{47} \mathrm{By}$ means of transmigration, it is possible for a dead mortal, whether he was a Chinese or Indian, to be reincarnated as an Indian or Buddhist deity in the otherworld. There are several accounts of the transmigration of historical figures into Buddhist otherworld bureaucratic gods during the early medieval period. They demonstrate how the Buddhist transformed Chinese perceptions of the other-world empire through accommodation of this resemblance.

\section{The Posthumous Transmigration of an Indian King into King Yama, the Lord of Hell, in Chinese Bud- dhist Scripture}

One of the earliest Chinese Buddhist narrations of the transmigration of a deceased Buddhist into an otherworld juridical deity can be found in an extraordinary account attributed to the Wen diyu jing 問地獄經 (“Sūtra on Questions on Hells”) and dating to the fifth century or earlier. This text describes how King Bimbisāra 毘(毗) 沙國王, a patron and follower of the Buddha, died in a battle against a King Weituoshi 維陀始王 and in the otherworld became Yama, Lord of Hell, subject to the Northern Celestial King, Vaiśravaṇa. Furthermore, King Bimbisāra’s eighteen ministers and his entire defeated army of millions followed him to Hell in order to assist him in governing the sinners. The ministers became the eighteen Hell-kings, who supervised different tortures in eighteen different Hells. ${ }^{48}$ The Wen diyu jing's account is probably the earliest enumeration in Buddhist scripture of transmigrated Hell-kings for each specific Hell, which has no precedent in early Indic texts. It is well documented in various Indian and Chinese sources that the real King Bimbisāra did not die in battle but was murdered by his son, King Ajātaśatru. ${ }^{49}$ The account of his transmigration into Yama therefore appears to be a forgery. How was the story composed and what was the motivation behind it? These questions were for many years overlooked by scholarship. In an earlier article, I traced the development of the idea of Bimbisāra's transmigration into the Lord of Hell and considered why, as Yama, he was subject to the Northern Celestial King. My findings suggested that the text was probably formulated from parallel/analogous conceptions of the roles and position of deceased kings or generals in the otherworld hierarchy in the

47 Zürcher, "Buddhist Influence on Early Taoism,” 123.

48 Jinglü yixiang, T 53. 2121. 258-260. Ziegler, "The Sinification of Buddhism as Found in an Early Chinese Indigenous Sūtra," 153-159. Chen, "In Search of the Origin of the Enumeration of Hellkings."

49 Radich, How Ajātaśatru was reformed. 
Chinese religious and Buddhist sources. First, the depiction of the transmigration of King Bimbisāra, as well as of his ministers and army, after a calamitous defeat recalls similar accounts of Chinese popular cults making sacrifices to "defeated armies and dead generals (or kings)" during the tumultuous early medieval period. The members of these cults believed that dead generals or kings and their millions of soldiers, particularly those who died in battle, turned into ghost kings and demonic soldiers in an unseen world (on earth) and spread diseases to humans if they were not propitiated. ${ }^{50}$ Textual sources show that Daoists and Buddhists alike dismissed these cults as profane, because they performed blood sacrifices, yet both also attempted to tame unruly ghost kings and integrate them into their respective pantheons, Daoist or Buddhist. Secondly, King Bimbisāra is linked to the Northern Celestial King in a passage about the afterlife fate of the Buddha's disciples in the Janavasabha Sutta (DN 18), the Shenisha jing 闍尼沙經 in the Chinese Dïrgha-āgama (T 1. 1: 34b4-36b23). Here the late King Bimbisāra approaches the Buddha and says that, because of his devotion to Buddhism, he has been reborn into the entourage of the Northern Celestial King and become a king of non-humans among the devas (celestial beings). ${ }^{51}$ The story of Bimbisāra's transmigration into Yama shows how Buddhists shrewdly accommodated local sacrificial cults by linking parallel and compatible beliefs in the transmigration of deceased kings or generals that could be found in both Buddhist and popular Chinese religious texts. It was frequently included in later medieval repentance and purgatory scriptures, such as the Lianghuang baocan 梁皇寶幟 (“Jewelled Repentance Dharma of Emperor Liang”, T 45. 1909). As the sūtra includes an account of the intermediate state between death and the next life, before the deceased are informed of their fate, it is considered a prototype for the later medieval (ninth or tenth century) Scripture on the Ten Kings. 十王經. ${ }^{52}$

\section{The Posthumous Transmigration of a Chinese General into King Yama in the Official Chinese Historical Record}

In the Suishu 隋書, the official history of the Sui dynasty (581-618 CE) edited in the seventh century CE, there is a legend about the famous General Han Qin 韓㩉 (alter-

50 Lin, “The Cult of Jiang Ziwen in Medieval China,” 357-375. Chen, "Liuchao Jiang Ziwen xinyang tanwei," 165-169. Li, "Nanchao suhoushen jici chutan minsu yanjiu," 112-120. Quan, "Nanchao de suhoshen xinyang," 39-44.

51 Chen, "In Search of the Origin of the Enumeration of Hell-Kings," 53-64.

52 Chen, "In Search of the Origin of the Enumeration of Hell-Kings;" Ziegler, "The Sinification of Buddhism as Found in an Early Chinese Indigenous Sūtra,” 158. 
natively called Han Qinhu 韓㩉虎, 538-592 CE), who was told before his death that he would become King Yama in the otherworld. It was later elaborated in a popular vernacular story, the Han Qinhu huaben 韓搨虎話本 (the “Storyteller's Script of General Han Qinhu”), one of the Tang transformation texts (唐代變文). The original version in the Suishu reads:

\footnotetext{
Not long afterwards, the neighbourhood mother saw an impressive regiment outside the house of General Han Qin, like that of a king. The mother was curious, so she asked them why they were there. One of them answered, 'We are coming to greet the king.' Then the whole regiment suddenly disappeared. Thereupon a person, who had suddenly become severely ill, ran in alarm to the house of Qin and said, 'I want to pay my respects to the king.' The entourage asked him: 'Which king is this?' He answered, 'It is King Yama.' Qin's soldiers tried to whip him, but Qin stopped them and said, 'It is satisfactory enough to be in the position of Supreme Pillar of State in my lifetime and then to die as King Yama.' He fell ill in his sleep and died within a few days. ${ }^{53}$
}

This legend recorded in the official history reflects not only the continuity of the old Chinese belief that a dead imperial official could take a bureaucratic position in the otherworld; it also further demonstrates acceptance of the fusion of this belief with the Buddhist concept of transmigration, making it possible for a Chinese general to be reborn as an Indian otherworld divinity. When a deceased Chinese high official could become King Yama, the Buddhist otherworld bureaucratic authority was no longer foreign, or part of a hybrid conception, but had become fully integrated as a Chinese Buddhist otherworld empire.

\section{How the Government of the Transmigration Cycle by the Otherworld Bureaucracy Replicates Living- World Imperial Administration}

In the seventh-century Ming bao ji 冥報記 (“The Record of Retribution from the Dark World”) written by Tang Lin 唐臨, a Buddhist who once served as President of the Ministry of Official Personnel Affairs 吏部尚書 at the Tang imperial court, there is a detailed description of the parallel positions of otherworld divinities and their counterparts in the living-world bureaucracy. It appears in a tale about a man from the commandery of Zhao 趙 called Lu Renqian 陸仁蒨, who encounters a ghost called Cheng Jing 成景 who says that he was in life the aide of the state governor during the Western Jin dynasty (265-316 CE) and is now, in the otherworld, an offi-

53 Wei Zheng et al., Suishu, 52:1341: [...] 無何, 其鄰母見㩉門下儀\%甚盛, 有同王者, 母異而問之. 其 中人曰: 「我來迎王.」忽然不見. 又有人疾篤, 忽驚走至㩉家曰: 「我欲謁王.」. 左右問曰: 「何王 也? 」答曰: 「閻羅王.」㩉子弟欲撻之, 㩉止之曰: 「生爲上柱國, 死作閻羅王, 斯亦足矣. 」因寢 疾, 數日竟. 
cial of Kingdom of Linhu 臨胡國. This kingdom is, like the state of Zhao, located on the north bank of the Yellow River. The ghost adds that the otherworld king of Linhu is actually the late King Wuling of Zhao state 趙武靈王 (340-295 BCE), who, according to historical accounts, starved to death during a rebellion in the Warring States period..$^{54}$ The kingdoms of the otherworld, the ghost explains, are all governed from Mount Tai; each month, envoys like himself are sent there to present a report. Lu Renqian befriends the ghost Cheng Jing, who arranges for one of his retinue to follow Lu Renqian and help him avoid misfortune by providing prophetic information from the otherworld administration. In return for this assistance, Chen Jing asks Renqian to give him food, as ghosts (even high-ranking ones) are always hungry; this is because one living-world meal is equivalent to a whole year's supply of food in the otherworld. Several years later, Renqian falls ill and asks Chen Jing for help. Chen Jing tells him that he still has more than twenty years to live, but Renqian might prefer to have his date of death brought forward to enable him to take advantage of an employment opportunity in the otherworld. An old classmate of his, called Zhao Wu, now Recorder on Mount Tai, would like him to die early and take a high position there in the otherworld administration. Though the ghost presents this as a rare chance of advancement, Renqian does not want to leave the world of the living prematurely. Chen Jing therefore advises him to send a petition for longer life to Mount Tai, accompanied by a painting of the Buddha. This is done, but Renqian, not being a believer in Buddhism, has doubts about the effectiveness of his petition. He asks Chen Jing to tell him how the transmigration cycle functions in the otherworld. ${ }^{55}$ After explaining the Buddhist concept of transmigration with the metaphor of the rankings of imperial bureaucrats, Chen Jing addresses the question of whether the Daoist petition is also worthwhile:

For Daoists, the Celestial Emperor presides over the six paths (of transmigration), called the Celestial Bureau. King Yama is like the Son of Heaven in the human world. The Lord of Mount Tai is the chief state secretary. The God who records the Five Paths is like the president of a government board. It is like our nation, parallel to the big states and commanderies. In every affair in the living world, the Daoist priest makes a petition upwards to ask for good fortune. The Celestial Bureau receives it and transmits it to King Yama. It says that on day so and so of month so and so, a person so and so makes a petition so and so. You should deal with it as reasonably as possible and not falsely accuse or abuse the person; Yama sincerely receives and implements it, just as people receive official edicts. Without good reason, the person cannot be acquitted; if there is a false charge, the person can make an appeal. How can you say it is of no benefit?

[Renqian] questioned further, 'How do Buddhists cultivate their merits?' Jing answered: 'The Buddha is the grand sage. Buddhists do not have paper circulation and transmission. Those who have cultivated Buddhist merits will be sincerely received by the celestial gods. They will often be treated with tolerance and forgiveness. A person with profound merits, even if he has

54 Simaqian, Shiji, 43:1815.

55 Ming bao ji, T. 51, 2082: 792-793. 
been put on the list of Evil Destinies, will not be chased and arrested. That is what I cannot understand and I do not know how it actually works. ${ }^{56}$

Regarding the interplay between Chinese Buddhism and Daoism, Zürcher points out that, while we tend to pay attention to the religious elites and their texts (the top levels of the Buddhist and Daoist pyramids), at a popular religious level, the two religions were integrated into a more or less indistinguishable mass of beliefs and practices. ${ }^{57}$ The story of Lu Renqian exemplifies how, at a popular level, Buddhist and early Chinese interpretations of afterlife fate had intertwined and merged by the later years of early medieval China. The Buddhist concepts of the cycle of transmigration and karmic retribution were commonly perceived by the Chinese populace as fully compatible with the Chinese belief in a parallel unseen world ruled by an imperial bureaucracy, headed by deceased kings and officers and focused on official paper-pushing related to the registration of the dead. In contrast to the description found in the fifth-century Jingdu sanmei jing discussed above, the Buddhist cosmological concept of the Six Paths is here governed by the Celestial Emperor, while King Yama is merely emperor in the otherworld empire, along with the Buddhist god in charge of the Five Paths and the eminent Lord of Mount Tai, the pivotal Chinese deity concerned with registering the dead, and that their bureaucratic roles closely parallel those of officials at the Chinese imperial court. Daoist petitions and rituals are not thought to conflict with Buddhist cultivation of meritorious deeds and devotion; both approaches are presented as effective and beneficial. By the end of the early medieval period (before the increasing popularity of Buddhist scriptures on esoteric and purgatory rituals in the Tang dynasty), this acculturated interpretation of the otherworld empire at the level of popular religion is not distinctly Buddhist or Daoist; it is Chinese.

\section{Conclusion}

Some scholars have suggested that a proto-bureaucracy was present in China as early as the late Shang dynasty (sixteenth century BCE-1046 BCE). ${ }^{58}$ Yet, it was only after the establishment of a more centralised, "de-feudalised" government during the Warring States period and at the beginning of the empire of the Qin and Han

56 Ming bao ji, T. 51, 2082: 793b. See also Gjertson, "A Study and Translation of the Ming-Pao Chi," 160-166, 298-312: 道者. 天帝總統六道. 是謂天曹. 閻羅王者. 如人天子. 太山府君尚書令. 錄五道神如 諸尚書. 若我輩國. 如大州郡. 每人間事. 道上章請福. 天曹受之. 下閻羅王云. 某月日得某甲訴云云. 宜 盡理勿令枕濫. 閻羅敬受而奉行之. 如人之奉詔也. 無理不可求免. 有枕必當得申. 可爲無盆也何. 又問. 佛家修福何如. 景曰. 佛是大聖. 無文書行下. 其修福. 天神敬奉. 多得寬宥. 若福厚者. 雖有惡道文簿. 不得追攝. 此非吾所識. 亦莫知其所以然.

57 Zürcher, "Buddhist Influence on Early Taoism," 140.

58 Creel, The Origins of Statecraft in China; Keightley, "The Religious Commitment." 
dynasties that Chinese imperial administration became a structured framework based on paper (wood-tablet)-pushing, close to the modern definition of bureaucracy. ${ }^{59}$ This change in political administration was reflected in contemporary perceptions of the otherworld, as we saw in the early accounts of communication between living-world and otherworld bureaucrats in the story of Dan from tomb I at Fangmatan, and the Former Han funeral texts. The Former Han funeral texts resemble official documents, petitioning otherworld bureaucrats or the earth god in the names of local bureaucrats or familial officials of the nobility. As the empire began to decline during the Later Han period, a different type of mortuary document emerged, the tomb-quelling text, characterised by additional religious ideas. The Celestial Emperor Envoy (modelled on the emperor's special envoy from the imperial court) replaced the local bureaucrat as the petitioner, and the texts became essentially religious documents, seeking special blessings and protection for the deceased and the bereaved family. The early development of Chinese perceptions of the otherworld as a counterpart of the bureaucratic empire in this world coincided with changes in political structure and social conditions. This is in line with Feuerbach's theory of the mirror-image of God. Similarly, scholars of early Indian Buddhism have pointed out that the assemblies of gods, role of deities like Indra, and otherworld methods of record-keeping described in early Buddhist scriptures mirror the practices of the Kṣatriya tribes at the time of the Buddha. This paper has sought to explain how these two otherworlds mirroring the different cultural milieus from which they originated merged to form a specifically Chinese conception of an otherworld hierarchy and bureaucracy after Buddhism was introduced into China.

Robert Campany has recently employed Michael Baxandall's reasoning to question the often rather reckless use of the term "influence" in discussion of Chinese religion. In Patterns of Intention, Baxandall wrote:

\begin{abstract}
If one says that $\mathrm{X}$ influenced $\mathrm{Y}$ it does seem that one is saying that $\mathrm{X}$ did something to $\mathrm{Y}$ rather than that $\mathrm{Y}$ did something to $\mathrm{X}$. [...] If we think of $\mathrm{Y}$ rather than $\mathrm{X}$ as the agent, the vocabulary is much richer and more attractively diversified: draw on, resort to, avail oneself of, appropriate from, have recourse to, adapt, misunderstand, refer to, pick up, take on, engage with, react to, quote, differentiate oneself from, assimilate oneself to, assimilate, align oneself with, copy, address, paraphrase, absorb, make a variation on, revive, continue, remodel, ape, emulate, travesty, parody, extract from, distort, attend to, resist, simplify, reconstitute, elaborate on, develop, face up to, master, subvert, perpetuate, reduce, promote, respond to, transform, tackle. ${ }^{60}$
\end{abstract}

In line with this pluralistic view of cultural influence, this paper has surveyed various textual sources for the perception of the Buddhist otherworld bureaucracy in the early medieval period: popular apocryphal scriptures of rentian jiao, Buddhist mortuary texts, the earliest enumeration of Hell-kings, the accounts of the transmi-

59 Creel, What is Taoism?, 126-127, 134. Weber, Essays in Sociology, 196.

60 Campany, Making Transcendents, 216; Baxandall, Patterns of Intention, 58-59. 
gration of a Chinese top official into Yama, and a popular story about how the otherworld empire operates. The results of this analysis show how a Buddhist perception of the otherworld based on the doctrines of a cycle of transmigration and karmic retribution gradually permeated Chinese religious beliefs about afterlife fate in early medieval China until it became an indispensable and indistinguishable part of it. The Account of the Days of the Eight Kings in the Jingdu sanmei jing demonstrates how a Chinese Buddhist otherworld empire was formulated by accommodating and amalgamating parallel concepts of abstinence days and the associated bureaucratic metaphors of periodic inspection and recording in Indian Buddhist and Chinese Daoist texts, which mirrored the respective structure of living-world authority. As a result, the fundamental Buddhist doctrines of the transmigration cycle and karmic retribution in rentian jiao were integrated into the Daoist pursuit of a longer life. Although Buddhist divinities became dominant in this hybrid otherworld empire, the Indian bureaucratic metaphor of the Kșatriya tribes relating to investigation and assemblies in the celestial courts (depicted in the text of The Four Great Kings) was submerged in the local model of Chinese imperial bureaucracy in the Account of the Days of the Eight Kings. This portrayal of a transformed Chinese Buddhist otherworld bureaucracy was also reflected in the early appearance of the Buddhist funeral passport, wherein Buddhist divinities supplanted Chinese deities as the chief authorities in typical Chinese mortuary documents. This form of Buddhist funeral passport is still in use today.

In addition, there is a certain similarity between the indigenous Chinese belief that deceased kings and officials take equivalent positions in the otherworld and the Buddhist concept that otherworld deities are subject to the cycle of death and rebirth and may be replaced by other deceased individuals. Yet, while the Chinese belief is usually confined within Chinese geographical boundaries and the influence of the ghost kings is often associated with the regions that they ruled whilst alive, the Buddhist theory of transmigration can be applied to any sentient beings regardless of geographical or ethnic barriers. This means that not only deceased Indians but also Chinese and people of other ethnic origins can be reborn as Indian Buddhist deities. Textual examination of the story of King Bimbisāra's transmigration into Yama reveals that the Buddhist textual reference in this story probably derives from the account of the afterlife fate of the Buddha's follower King Bimbisāra given in the Janavasabha Sutta (the Shenisha jing). The latter reports that, because of his faith in the Buddha's teaching during his lifetime, the King declared after his death: "I am reborn into the communion of the great King Vessavana (the Northern Celestial King). Deceased as a human king, I have in Heaven become a non-human king." 61 This statement about the fate of a deceased king seems to parallel indigenous Chinese beliefs. In addition, by adapting the narrative of defeated warrior kings and millions of soldiers turning to menacing underworld ghost kings and sol-

61 DN II 206, trans. by Rhys Davids, 240. 
diers after their death in battle from the cults of "defeated armies and dead generals (or kings)", the story of King Bimbisāra's transmigration as Yama presents an underworld bureaucracy in Buddhist order. Not only is the underworld ruled by Yama, incarnated by a deceased Buddhist king as a warrior king defeated in battle, it seems that the Chinese belief in the regional gods of popular sacrificial cults was also conceptualised and transformed into the belief according to which the ministers of King Bimbisāra were reborn as Hell-kings in the Hells connected to different tortures. This apocryphal story, containing what is probably the earliest enumeration of the Hell-kings, is another text exemplifying Buddhist efforts to absorb local popular cults into its otherworld system by integrating parallel religious concepts.

By the end of the early medieval period, basic Buddhist doctrines about the otherworld were no longer foreign, but had become part of Chinese religions at the popular level. The inclusion in the official imperial history of the legend of Han Qin being received by a ghost army and becoming King Yama signifies not only that a dead Chinese could rule the otherworld empire, but also that Buddhist concepts of the otherworld had become completely embedded in Chinese beliefs. The portrayal of the otherworld bureaucratic empire in the story of Lu Renqian's encounter with Chen Jing indicates the inclusiveness of Buddhism and popular Chinese religions during the process of interplay and amalgamation. Indian Buddhist and early Chinese beliefs about the otherworld and individual afterlife fates co-existed and accommodated each other's compatible ideas.

\section{Bibliography}

\section{Primary Sources}

Bencao jing 本草經. Edited by Cao Yuanyu 曹元宇. Shanghai: Shanghai Kexuejishu chubanshe, 1987.

Dialogues of the Buddha, translated from the Pāli of the Dīgha nikāya. Vol. 2. Edited by Thomas W. Rhys Davids and Caroline A. F. Rhys Davids. London: Frowde, 1910.

Guang ya 廣雅. Zhang Yi 張揖. The Version from the Qinding Siku Quanshu (“Complete Imperial Collection in Four Branches of Literature") 《欽定四庫全書》 本

Hou Han shu 後漢書. Fan Ye 范瞱. Hong Kong: Zhonghua shuju, 1971.

Jingdu sanmei jing 淨度三昧經 W. (Fang Guangchan 方廣錩 ed. Zangwai fojiao wenxian 藏外佛教文 獻 Buddhist Texts not contained in the Tripițaka), Beijing: Zongjiao wenhua, Vol. 7, No. 63. Jinglü yixiang 經律異相. Baochang 寶唱 of the Liang dynasty. T. 53, No. 2121.

Manorathapūraṇī. "Buddhaghosa's Commentary on the Anguttara-nikāya." Edited by Max Walleser and Hermann Kopp. London: Oxford University Press, 1930.

Ming bao ji 冥報記. Tang Lin 唐臨. T. 51, No. 2082.

Mingyi bielu 名醫別錄. Edited by Shang Zhijun 尚志鈞. Beijing: Renminweisheng chubanshe, 1986. Shiji 史記. Simaqian 司馬遷. Beijing: Zhonghua shuju, 1971.

Suishu 隋書. Wei Zheng 魏徵. Beijing: Zhonghua shuju, 1973. 
Taozhai cangshi ji 陶齋藏石記. Edited by Duan Fang 端方. n. p.: n. p., 1909. Za Piyu Jing 雜譬喻經 T. 4, No. 205.

\section{Secondary Literature}

Abe, Stanley K. Ordinary Images. Chicago: The University of Chicago Press, 2002.

The Archaeological Team of Han Tomb 168. "Hubei jiangling fenghuangshan yiliuba hao hanmu fajue jianbao 湖北江陵鳳凰山一六八號漢墓發掘簡報.” Wenwu, no. 9 (1975): 1-19.

Asami Naoichirō 浅見直一郎. “Chūgoku Nambokuchō jidai no sōsō bunshu - Hokusei Muhei yonnen 'O Kō hi zuisō ibutsuso' o chūshin ni - 中国南北朝時代の葬送文書-北斉武平四年『王江妃 随葬衣物疏』を中心に.” Kodai bunka 古代文化 42, no. 4 (1990): 1-19.

Bai Bin 白涁. “Wujin nanchao maidiquan mingci he yiwushu de daojiao kaogu yanjiu 吳晉南朝買地 券,名刺和衣物疏的道教考古㸴究.” PhD diss., Sichuan University, 2001.

Bai Bin and Dai Lijuan 白涁; 代麗鵑. “Shicong kaohucailiao kan Nüqing guilü dechengshushidai he liuxingdiyu 試從考古材料看女青鬼律》的成書時代和流行地域。” Congjiaoxu yanjiu 宗教學㗏究, no. 1 (2007): 6-17.

Baun, Jane. Tales from Another Byzantium. Celestial Journey and Local Community in the Medieval Greek Apocrypha. Cambridge: Cambridge University Press, 2007.

Baxandall, Michael. Patterns of Intention. On the Historical Explanation of Pictures. New Haven: Yale University Press, 1985.

Campany, Robert Ford. Making Transcendents: Ascetics and Social Memory in Early Medieval China. Honolulu: University of Hawai'i Press, 2009.

Cedzich, Angelika. "Ghosts and Demons, Law and Order: Grave Quelling Texts and Early Taoist Liturgy." Taoist Resources 4, no. 2 (1993): 23-35.

Chen, Frederick Shih-Chung. "The Transformation of Concepts of Bureaucratization of the Other World in Early Medieval China: From Buddhist Perspectives.” DPhil diss., University of Oxford, 2010.

Chen, Frederick Shih-Chung. "Buddhist Passports to the Other World: A Study of Modern and EarlyMedieval Chinese Buddhist Mortuary Documents." In Buddhist Funeral Cultures of Southeast Asia and China, edited by Paul Williams and Patrice Ladwig, 261-286. Cambridge: Cambridge University Press, 2012.

Chen, Frederick Shih-Chung. "Who Are the Eight Kings in the Samādhi-Sūtra of Liberation through Purification? Otherworld Bureaucrats in India and China." Asia Major, 3rd ser., 26, no. 1 (2013): 55-78.

Chen, Frederick Shih-Chung. "In Search of the Origin of the Enumeration of Hell-kings in an Early Medieval Chinese Buddhist Scripture: Why Did King Bimbisāra Become Yama after his Disastrous Defeat in Battle in the Wen diyu jing ('Sūtra on Questions on Hells')." Buddhist Studies Review 31, no. 1 (2014): 53-64.

Chen Shengyu 陳聖宇. “Liuchao Jiang Ziwen xinyang tanwei 六朝蔣子文信仰探微”: Zongjiaoxue yanjiu 宗教学研究 1 (2007): 165-169.

Chen Zhi 陳直. “Guanyu 'Jiangling cheng' gao ‘dixia cheng’, 關於“江陵丞”告 ‘地下丞”.” Wenwu, no. 12 (1977).

Creel, Herrlee G. The Origins of Statecraft in China. Chicago: University of Chicago Press, 1970.

Creel, Herrlee G. What is Taoism? and Other Studies in Chinese Cultural History. Chicago: University of Chicago Press, 1970.

Dudink, Adrianus. "Nüqing guilü." In The Taoist Canon: A Historical Companion to the Daozang 道 教通考. Vol. 1, edited by Kristofer Schipper and Franciscus Verellen, 127-129. Chicago: University of Chicago Press, 2004. 
Falkenhausen, Lothar von. "Sources of Taoism: Reflections on Archaeological Indicators of Religious Change in Eastern Zhou China.” Taoist Resources 5, no. 2 (1994): 1-12.

Feuchtwang, Stephan. The Imperial Metaphor. Popular Religion in China. London: Routledge, 1992. Feuerbach, Ludwig. The Essence of Christianity. Translated by George Eliot. New York: Harper, 1957. Gjertson, D. E. “A Study and Translation of the Ming-Pao Chi. A T'ang Dynasty Collection of Buddhist Tales.” PhD diss., Stanford University, 1975.

Gombrich, Richard F. Precept and Practice: Traditional Buddhism in the Rural Highlands of Ceylon. London: Kegan Paul International, 1995.

Gregory, Peter N. "The Teaching of Men and Gods: The Doctrinal and Social Basis of Lay Buddhist Practice." In Studies in Ch'an and Hua-yen. Studies in East Asian Buddhism 1, edited by Robert M. Gimello and Peter N. Gregory, 253-319. Honolulu: University of Hawaii Press, 1985.

Gregory, Peter N. Inquiry into the Origin of Humanity. An Annotated Translation of Tsung-mi's Yüan jen lun, with a Modern Commentary. Honolulu: University of Hawaii Press, 1995.

Hansen, Valerie. "The Path of Buddhism into China: The View from Turfan.” Asia Major, 3rd ser., 11, no. 2 (1998): 37-66.

Harper, Donald. “Resurrection in Warring States Popular Religion.” Taoist Resources 5, no. 2 (1994): 13-28.

Huang Shou 黄绶. Lianghan xingzhengshi shouce, 兩漢行政史手冊. Henan: Zhongzhou guji chubanshe, 1991.

Hubeisheng jingzhou bowuguan 湖北省荆州博物館, ed. Jingzhou gaotai qinhanmu: yihuang gonglu jingzhou duan tianye kaogu baogao zhi yi 荆州高台秦漢墓:宜黃公路荆州段田野考古報告之一 = Excavation of the Qin-Han dynastic graveyard at Gaotai in Jingzhou: one of the archaeological reports from Jingzhou section of the Yi-huang highway project. Beijing: Kexue chubanshe, 2000.

Hubeisheng wenwu kaogu yanjiusuo suizhoushi kaogudui 湖北省文物考古㸴究, 隨州市考古隊, ed. Suizhou kongjiapo hanmujiandu 隨州孔家坡漢墓簡牘. Beijing: Wenwu chubanshe, 2006.

The Hunan Provincial Museum and IAAS. “Changsha mawangdui er san hao hanmu fajue jianbao 長 沙馬王堆二三號漢墓發掘簡報.” Wenwu, no. 7 (1974): 39-48.

Ikeda On 池田溫. “Chugoku rekidai boken ryakko 中國歷代墓券略考.” Toyo bunka kenkyujo kiyo 東 洋文化硏究所紀要 86 (1981): 193-278.

Keightley, David N. “The Religious Commitment: Shang Theology and the Genesis of Chinese Political Culture.” History of Religions 17, no. 3-4 (1978): 211-225.

Lai, Whalen W. "The Earliest Buddhist Religion in China: T'i-wei Po-li Ching and Its Historical Significance." In Buddhist and Taoist Practice in Medieval Society, edited by David W. Chappell, 1035. Vol. 2, Buddhist and Taoist Studies. Honolulu: University of Hawaii Press, 1987.

Law, Bimala C. Some Kșatriya Tribes of Ancient India. Calcutta: Thacker, Spink \& Co, 1923.

Law, Bimala C. Heaven and Hell in Buddhist Perspective. Calcutta: Thacker, Spink \& Co, 1925.

Li Xueqin 李學勤. “Fangmatan jianzhong de zhiguai gushi 放馬灘簡中的志怪故事”. Wenwu, no. 4 (1990): 43-47.

Li Hongyan 李紅艷. “Nanchao suhoushen jici chutan minsu yanjiu 南朝”蘇侯神” 祭祀初探民俗砶 究.” Folklore Studies 4 (2005): 112-120.

Li Zhitian 黎志添. “Nüqing guilü yu caoqi tianshidao dixia shijie de guanliaohua wenti 女青鬼律與 早期天師道地下世界的官僚化問題.” In Daojiao yanjiu yu Zhongguo zongjiao wenhua 道教㸴究 與中國宗教文化, edited by Li Zhitian, 2-36. Hong Kong: Zhonghua shuju, 2003.

Lin Fu-shih 林富士. “The Cult of Jiang Ziwen in Medieval China.” Cahiers d'Extrême-Asie 10 (1998): 357-375.

Liu Cunren [Liu Ts’un-yan] 柳存仁. “Was Celestial Master Zhang a Historical Figure?” In Daoism in History. Essays in Honour of Liu Ts'un-yan, edited by Benjamin Penny, 219-226. Oxon: Routledge, 2006. 
Liu Yi 劉屹. Jingtian yu chongdao: zhonggu jingjiao daojiao xingcheng de sixiangshi beijing 敬天與 崇道: 中古經教道教形成的思想史背景. Beijing: Zhonghua shuju, 2005.

Liu Zhaorui 劉昭瑞. “Anducheng yu Wuyijun 安都丞與武夷君.” Wenshi 文史 59, no. 2 (2002): 51-59. Miyasaka Yūshō 宮坂有勝. Bukkyō no kigen 伀教の起源. Tokyo: Sankibo Busshorin, 1971.

Norman, K. R. Collected Papers. Vol. 2. Oxford: Pali Text Society, 1991.

Peterson, Thomas H. "The Demon Statute of Feminine Verdure: A Preliminary Study.” Master's thesis, Indiana University, 1992.

Qiu Xigui [Chiu Hsi-kuei] 歨錫圭. “Hubei jiangling fenghuangshan shihao hanmu chutu jiandu kaoshi 湖北江陵鳳凰山十號漢墓出土簡覑考釋.” Wenwu, no. 7 (1974): 49-63.

Quan Jiayu 權家玉. “Nanchao de suhoshen xinyang 南朝的“蘇侯”神信仰.” Journal of Nanjing Xiaozhuang University 2 (2010): 39-44.

Radich, Michael. How Ajātaśatru Was Reformed: The domestication of "Ajase" and Stories in Buddhist History. Tokyo: International Institute for Buddhist Studies of the International College for Postgraduate Buddhist Studies. 2011

Salomon, Richard. Indian Epigraphy. A Guide to the Study of Inscriptions in Sanskrit, Prakrit, and the other Indo-Aryan Languages. New York: Oxford University Press, 1998.

Schopen, Gregory. Buddhist Monks and Business Matters. Still More Papers on Monastic Buddhism in India. Honolulu: University of Hawai'i Press, 2004.

Seidel, Anna. "Traces of Han Religion in Funeral Texts Found in Tombs." In Dōkyō to shūkyō bunka 道教と宗教文化, edited by Akizuki Kan’ei 秋月觀, 21-57. Tokyo: Hirakawa Shuppansha, 1987.

Strickmann, Michel. Chinese Magical Medicine. Stanford: Stanford University Press, 2002.

Suzuki Yoshijirōo鈴木由次郎. Kan'eki kenkyū 漢易研究. Tokyo: Meitoku Shuppansha, 1963.

Tamamuro Taijo 圭室諦成. Sōshiki Bukkyō 葬式仏教. Tokyo: Daihorinkaku, 1963.

Taylor, John H. Journey through the Afterlife. Ancient Egyptian Book of the Dead. London: British Museum Press, 2010.

Tokuno, Kyoko. "Byways in Chinese Buddhism: The Book of Trapusa and Indigenous Scriptures." PhD diss., University of California, 1994.

Tsukamoto Zenryū 塚本善隆. Shina Bukkyō shi kenkyū: Hokugi-ben 支那仏教史硎究: 北魏篇. Tokyo: Kōbundō, 1969.

Weber, Max. From Max Weber: Essays in Sociology. Edited by Hans H. Gerth and Charles W. Mills. London: Kegan Paul, 1948.

Wu Rongzeng 吳榮曾. “Zhenmuwen zhong suo jiandao de donghan daowu guanxi 鎭墓文中所見到 的東漢道巫關係.” Wenwu, no. 3 (1981): 56-63.

Xing Yitian 邢義田. “Hunan longshanliye J1(8)157 he J1(9)1-12hao qindu de wenshu gocheng, biji he yuandang cunfang xingshi (lienzai er). 湖南龍山里耶 J1(8)157 和 J1(9)1-12 號秦覑的文書構成, 筆跡和原檔存放形式(連載二." Bamboo and Silk Manuscripts 2005. http://www.bsm.org.cn/ show_article.php?id=78. [accessed 1 July, 2019]

Ziegler, Harumi Hirano. "The Sinification of Buddhism as Found in an Early Chinese Indigenous Sūtra: A Study and Translation of the Fo-shuo Ching-tu Sab-mei Ching (Samādhi-Sūtra of Liberation through Purification)." PhD diss., University of California, 2001.

Zürcher, Erik. "Buddhist Influence on Early Taoism: A Survey of Scriptural Evidence." T'oung Pao 66 (1980): 84-147. 